\title{
Foliar Adaptations in Aster hispidus var. insularis (Asteraceae)
}

\author{
Tunala $^{1}$, Hiroshi Hayakawa ${ }^{1}$, Yukio Minamiya ${ }^{1}$, Stephan W. Gale ${ }^{2}$, Jun Yokoyama ${ }^{3}$, \\ Ryo Arakawa ${ }^{1} \&$ Tatsuya Fukuda ${ }^{1}$ \\ ${ }^{1}$ Faculty of Agriculture, Kochi University, Kochi, Japan \\ ${ }^{2}$ Kadoorie Farm \& Botanic Garden, Hong Kong, China \\ ${ }^{3}$ Faculty of Science, Yamagata University, Kojirakawa, Japan \\ Correspondence: Tatsuya Fukuda, Faculty of Agriculture, Kochi University, Kochi, Japan. Tel: 81-888-645-140. \\ E-mail: tfukuda@kochi-u.ac.jp
}

Received: June 15, 2012 Accepted: July 10, 2012 Online Published: July 12, 2012

doi:10.5539/jps.v1n2p19 URL: http://dx.doi.org/10.5539/jps.v1n2p19

\begin{abstract}
A comparative study of leaf morphology of Aster hispidus and its coastal variety, A. hispidus var. insularis revealed that the latter has larger and thicker leaves than the former. The anatomical analysis indicated that the cell number of the leaf was lower but the cell size was larger in A. hispidus var. insularis. The reduction of cell number in the leaves of $A$. hispidus var. insularis was compensated by an increase in cell volume while the expansion of cells could be considered an adaptive strategy to coastal environments that allowed saving of water in the plant body. Salinity and drought seemed to have played a crucial role in the ecotypic differentiation.
\end{abstract}

Key words: anatomical analysis, Aster hispidus var. insularis, cell numbers, cell width, leaf morphology

\section{Introduction}

The existence of locally adapted ecotypes implies that disruptive selection favours alternative trait combinations in different environments; this suggests that trade-offs which are generated by ecological, morphological, physiological and genetic constraints are important determinants of diversification (Phillimore \& Price, 2009). Such variation in plant populations is frequently found where water availability varies abruptly over short spatial scales (Jackson \& Jobbgy, 2005). For example, coastal areas are characterised by open, sandy, or rocky habitats with weakly developed soils, and plants in these areas face severe droughts. Because of the accumulation of $\mathrm{Na}^{+}$ in soils of coastal areas, plants are also impeded in their water uptake owing to osmotic stress between the soil and plant roots (Matoh, 2001). Moreover, the absorbed $\mathrm{Na}^{+}$in plant bodies is concentrated in the leaves and causes a decrease in the osmotic potential of cells, thereby causing dehydration. In other words, this salt stress induces water stress (Kasperi et al., 2009). In such situations, roots, stems, or leaves can store water and the development of storage abilities is associated with environments subjected to drought. Thus, species with such drought-tolerant ecotypes can provide excellent systems for studying the mechanisms of local adaptations.

Aster hispidus Thunb. is widely distributed across China, Korea and Japan, and is found in lowland open fields and grasslands (Figure 1 I). It has four intraspecific taxa in Japan, namely, A. hispidus var. leptocladus (Makino) Okuyama, A. hispidus var. koidzumianus (Kitam.) Okuyama, A. hispidus var. tubulosus K.Asano ex T. Shimizu and $A$. hispidus var. insularis (Makino) Mot.Ito (Kitamura, 1982; Yonekura \& Kajita, 2003). Of these, A. hispidus var. leptocladus is found in serpentine areas of central Honshu, Kyushu and Shikoku, A. hispidus var. koidzumianus occurs along the riverside in Kyushu, A. hispidus var. tubulosus grows in central Honshu with the characteristic tubular flowers (homogamous heads with disc florets) and A. hispidus var. insularis is restricted to coastal areas of western Shikoku and eastern Kyushu (Kitamura, 1982; Ito \& Soejima, 1995; Shimizu, 1997). Conversely, these varieties could be result of ecotypic differentiation in A. hispidus in Japan driven by different ecological factors prevailing in the habitats it occupied. To substantiate the premise, the study by Hayakawa et al. (2012) involving A. hispidus and of the stenophyllous A. hispidus var. leptocladus showed decreased cell number of the horizontal axis of a leaf based as an adaptation. To clarify the whole aspect of ecotype differentiation in $A$. hispidus, there is a need to know the morphological and anatomical characteristics of other ecotypes as well. 


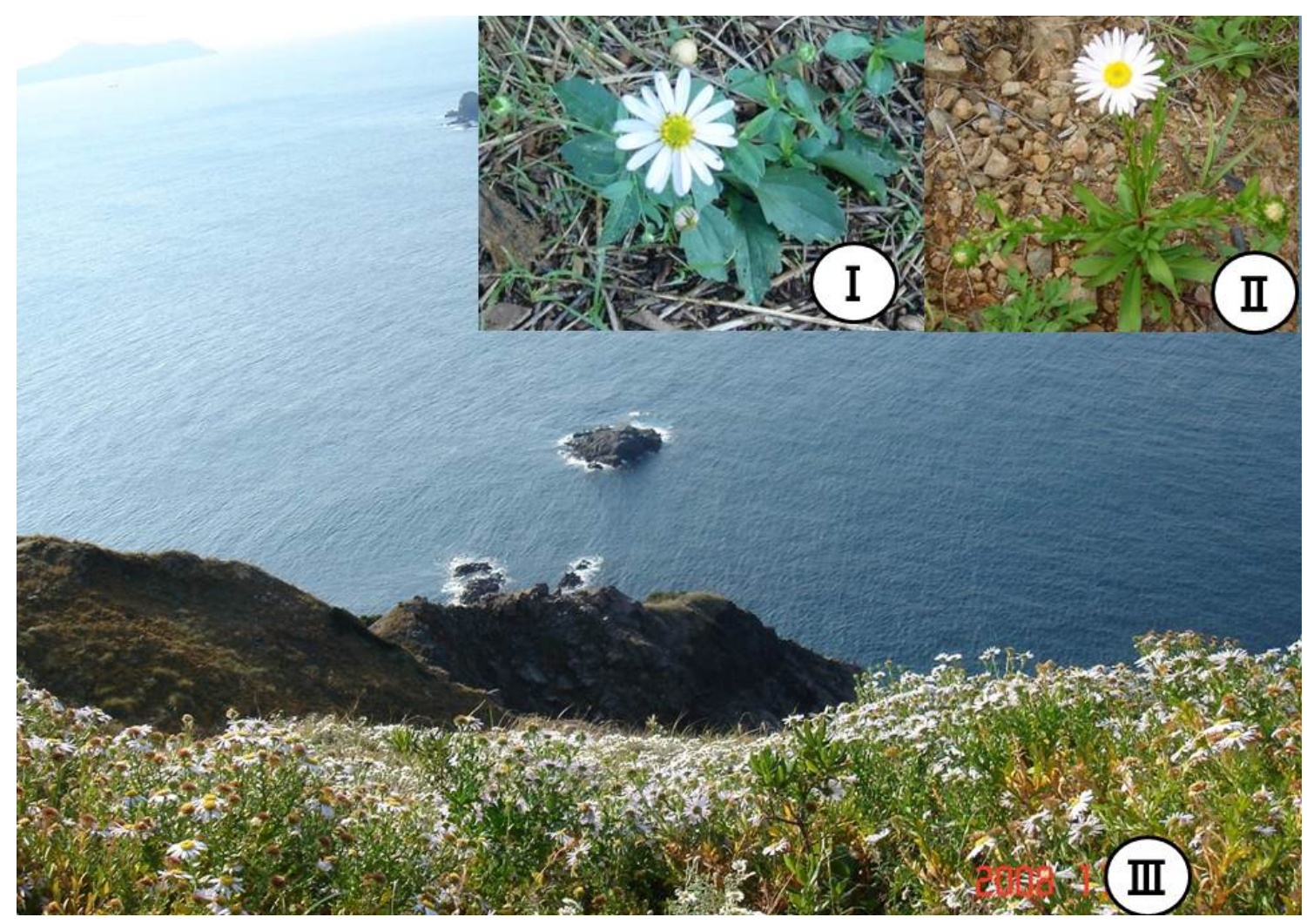

Figure 1. Aster hispidus varieties. (I) Aster hispidus var. hispidus, (II) A. hispidus var. insularis, and (III) Habitat of A. hispidus var. insularis.

Aster hispidus var. insularis has thicker stems and leaves than A. hispidus var. hispidus (Kitamura, 1982). Anatomical analyses are indispensable to discover whether the bases of the morphological differences of leaves between the two varieties are from the size and orientation of their cells. It remains unclear in the absence of such a comparative study between the two varieties. Besides, A. hispidus var. hispidus and A. hispidus var. insularis provide an opportunity to discuss the development of leaf form variation as a specialization to coastal environment. Therefore, we conducted the morphological and anatomical analyses using A. hispidus var. insularis to divulge such adaptive mechanism and the attendant foliar morphological differentiation.

\section{Materials and Methods}

Leaves of Aster hispidus var. hispidus and A. hispidus var. insularis were collected from the field in 2008 at flowering time (Figure 2, Table 1). For the morphological analysis, we measured the length, width, and thickness of stem leaves at the middle part of plant height for each sample. We analysed 226 leaves from 15 individuals in A. hispidus var. hispidus and 115 leaves from 26 individuals in A. hispidus var. insularis. Measurements were made using digital callipers. Leaf measurements were taken from the fully expanded leaves at the middle part of plant height, ensuring the same level of development. 


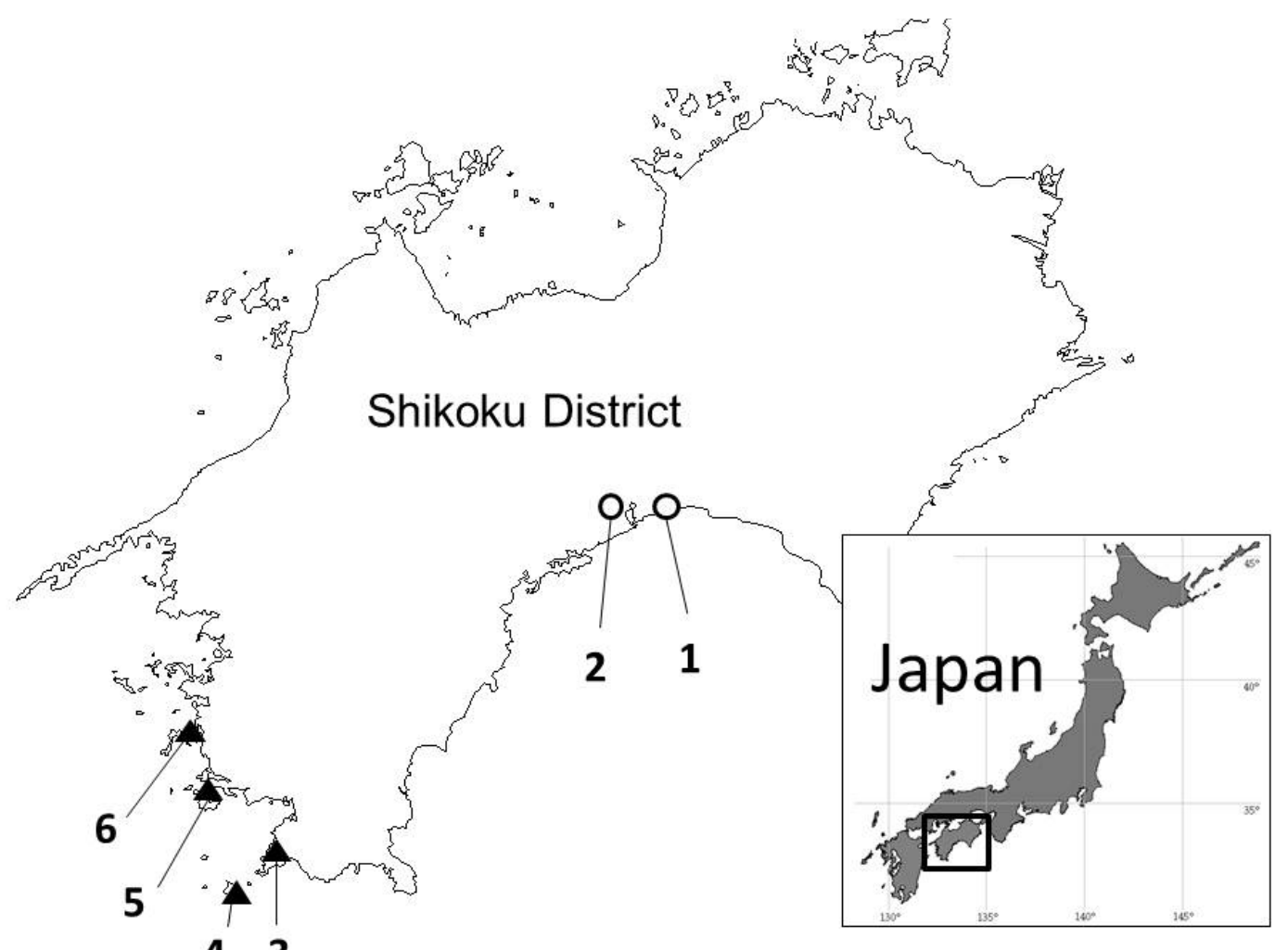

Figure 2. Sampling areas in this study

○, Aster hispidus var. hispidus; $\boldsymbol{\Lambda}$, A. hispidus var. insularis. See Table 1 for other abbreviations.

Table 1. Sampling localities used in this study

\begin{tabular}{|c|c|c|c|}
\hline Species & No.Locality & Latitude & Longitude \\
\hline \multirow[t]{2}{*}{ Aster hispidus var. hispidus } & 1 Monobe, Nankoku City, Kochi Prefecture & N333' & E1334' \\
\hline & 2 Mt. Hitsuzan, Kochi City, Kochi Prefecture & N33운 & E1333' \\
\hline \multirow[t]{4}{*}{ A. hispidus var. insularis } & $\begin{array}{l}\text { Kashiratsudoi, Hata-Gun Ootuki-Cho, } \\
\text { Kochi Prefecture }\end{array}$ & $\mathrm{N} 32^{\circ} 48^{\prime}$ & $\mathrm{E} 132^{\circ} 41^{\prime}$ \\
\hline & 4 Okinoshima Island, Sukumo City, Kochi Prefecture & $\mathrm{N} 32^{\circ} 43^{\prime}$ & $\mathrm{E} 132^{\circ} 32^{\prime}$ \\
\hline & $\begin{array}{l}\text { Uchidomari, Minamiuwa-Gun Ainan-Cho, } \\
\text { Ehime Prefecture }\end{array}$ & $\mathrm{N} 32^{\circ} 56^{\prime}$ & $\mathrm{E} 132^{\circ} 29^{\prime}$ \\
\hline & 6 Matsugahana, Uwajima City, Ehime Prefecture & $\mathrm{N} 33^{\circ} 3^{\prime}$ & $\mathrm{E} 132^{\circ} 28^{\prime}$ \\
\hline
\end{tabular}

For the anatomical analysis, the leaves were fixed in a solution of formaldehyde, ethanol and acetic acid (FAA). Leaf index (the ratio of length and width) was calculated in order to determine the leaf shape. To count the number of cells on the blade, the surfaces of leaves were replicated using Suzuki's Universal Micro-Printing (SUMP) method. The middle part of the blade along the midrib was analyzed to determine the number of cells on the blade. The same SUMP image was analysed 10 times for each trait using a light microscope (Figure 3). To observe the palisade cells, the fixed leaves were dehydrated by immersion in a graded ethanol series and then embedded in Histparaffin to section at a thickness of eight $\mu \mathrm{m}$. The widest part of the blade was analyzed to determine the height of epidermal cells (Figure 4). Slides were examined using a light microscope. Statistical analyses were performed using a $t$-test to compare the characteristics of the two varieties. Since the leaf index in 
either population was not normally distributed, nonparametric pairwise comparison was made (Mann-Whitney $U$ test).

(A)

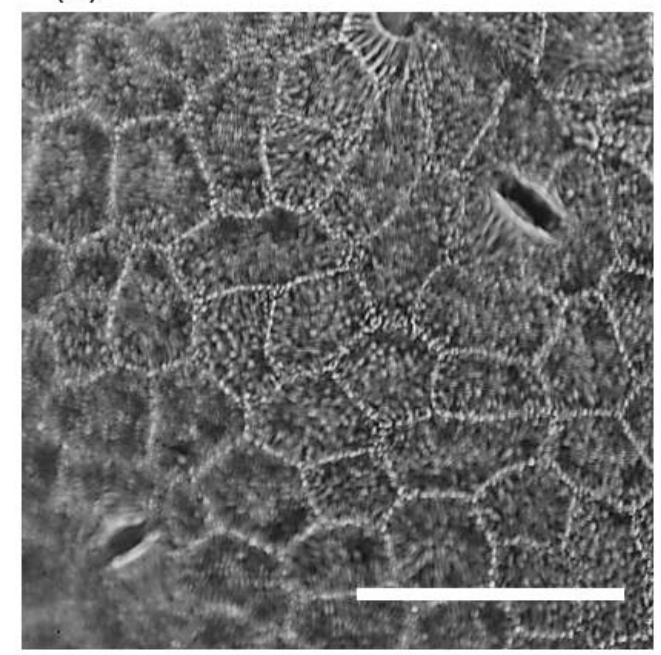

(B)

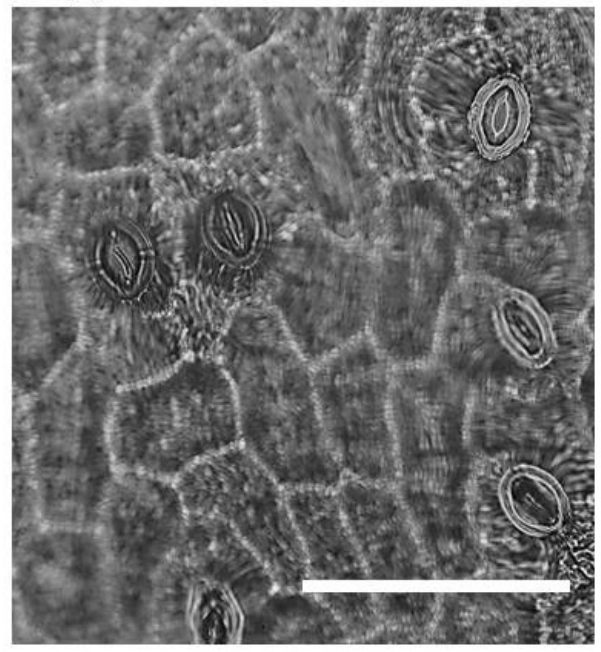

Figure 3. Comparison of the size of epidermal cells of (A) Aster hispidus var. hispidus and (B) A. hispidus var. insularis. Bar $=100 \mu \mathrm{m}$.

(A)

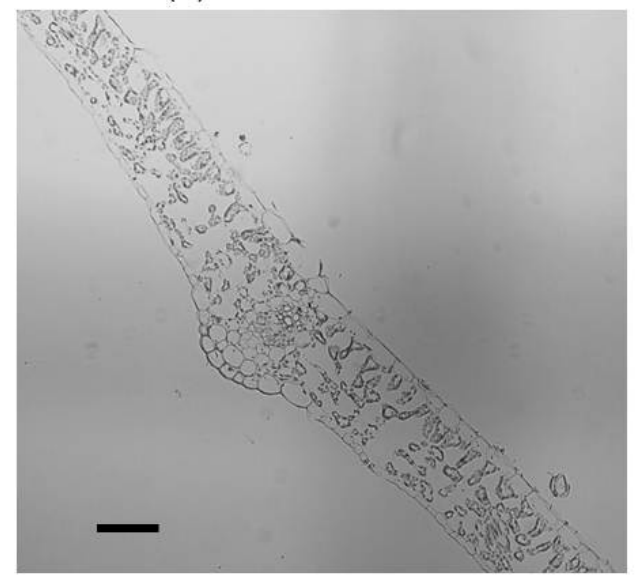

(B)

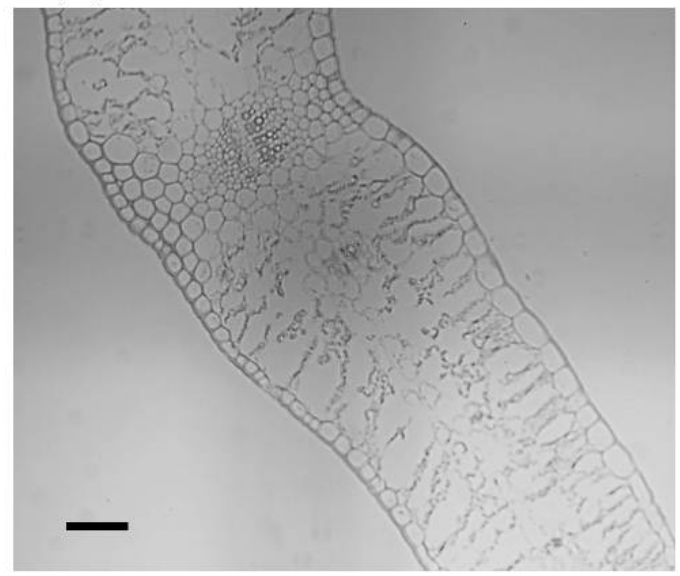

Figure 4. Transverse sections of a leaf (A) Aster hispidus var. hispidus and (B) A. hispidus var. insularis. Bar $=100 \mu \mathrm{m}$.

\section{Results}

Leaves of Aster hispidus var. insularis were significantly longer and wider than those of A. hispidus var. hispidus $(P<0.01)$. The leaf size was $30.65 \pm 6.49 \times 4.69 \pm 1.35 \mathrm{~mm}^{2}$ and $45.59 \pm 17.83 \times 8.17 \pm 1.71 \mathrm{~mm}^{2}$ for $A$. hispidus var. hispidus and $A$. hispidus var. insularis, respectively (Table 2). The leaf indices were $6.9 \pm 1.8$ and $4.6 \pm 0.9$ for $A$. hispidus var. hispidus and A. hispidus var. insularis, respectively, and the difference between the two varieties was significant based on the Mann-Whitney $U$ test $(P<0.01)$. The leaves of $A$. hispidus var. insularis $(0.45 \pm 0.10 \mathrm{~mm})$ were twice thicker $A$. hispidus var. hispidus $(0.18 \pm 0.02 \mathrm{~mm})$. 
Table 2. Morphological and anatomical measurements (average \pm standard deviation) of Aster hispidus var. hispidus and var. insularis

\begin{tabular}{lccc}
\hline Trait & var. hispidus & var. insularis & Significance \\
\hline Morphological measurement & & & \\
$\quad$ Leaf length $(\mathrm{mm})$ & $30.65 \pm 6.49$ & $45.59 \pm 17.83$ & $* *$ \\
$\quad$ Leaf width $(\mathrm{mm})$ & $4.69 \pm 1.35$ & $8.17 \pm 1.71$ & $* *$ \\
$\quad$ Leaf index & $6.9 \pm 1.8$ & $4.6 \pm 0.9$ & $* *$ \\
$\quad$ Leaf thickness $(\mathrm{mm})$ & $0.18 \pm 0.02$ & $0.45 \pm 0.10$ & $* *$ \\
Anatomical measurement & & & \\
$\quad$ Epidermal cell length $(\mu \mathrm{m})$ & $38.83 \pm 6.63$ & $46.32 \pm 6.60$ & $* *$ \\
$\quad$ Epidermal cell width $(\mu \mathrm{m})$ & $37.68 \pm 6.21$ & $40.30 \pm 4.73$ & $*$ \\
$\quad$ Epidermal cell numbers in longitudinal direction & $1240 \pm 393$ & $779 \pm 249$ & $* *$ \\
$\quad$ Epidermal cell numbers in latitudinal direction & $266 \pm 117$ & $180 \pm 60$ & $* *$ \\
$\quad$ Epidermal cell height at adaxial side $(\mu \mathrm{m})$ & $16.83 \pm 4.59$ & $31.78 \pm 5.64$ & $* *$ \\
\hline
\end{tabular}

$* *$ and $*$ indicate $p<0.01$ and $p<0.05$, respectively, according to the $t$-test.

The data of Aster hispidus var. hispidus are after Hayakawa et al., 2012 and present study.

Epidermal cells at adaxial side of Aster hispidus var. insularis were significantly longer and wider than those of A. hispidus var. hispidus ( $P=0.01$ and $P=0.05$, respectively). The length and width of the cells were $38.83 \pm$ 6.63 and $37.68 \pm 6.21 \mu \mathrm{m}$ for $A$. hispidus var. hispidus and $46.32 \pm 6.60$ and $40.30 \pm 4.73 \mu \mathrm{m}$ for A. hispidus var. insularis. The epidermal cell numbers in longitudinal and latitudinal directions of leaves were found to be $1240 \pm$ 393 and $266 \pm 177$ for $A$. hispidus var. hispidus and $779 \pm 249$ and $180 \pm 60$ for A. hispidus var. insularis (Table 2). The cell numbers of $A$. hispidus var. insularis were significantly lower than those of $A$. hispidus var. hispidus in both directions $(P=0.01)$.

The cross sections in a sample of leaves revealed the adaxial epidermal cell height to be $31.78 \pm 5.64 \mu \mathrm{m}$ for Aster hispidus var. insularis and $16.83 \pm 4.59 \mu \mathrm{m}$ for A. hispidus var. hispidus, and the difference is significant $(P=0.01)$.

\section{Discussion}

Our results revealed that the leaves at the middle part of plant height of the coastal ecotype Aster hispidus var. insularis are not only larger but also thicker than those of its inland variety, A. hispidus var. hispidus (Table 2). Changes in features of leaves are commonly observed in plants subjected to increased soil salinity, as in the case of mangal plants such as Laguncularia racemosa (L.) C.F. Gaertn. (Biebl \& Kinzel, 1965) and Avicennia germinans L. (Suárez \& Sobrado, 2000). In the latter, leaf succulence was caused by increased leaf water content and subsequent accumulate large amount of solute, without an increase in the osmotic pressure of cells (Suárez \& Sobrado, 2000). Tadano (1993) also reported that thicker and more succulent leaves maintain low salinity levels in the leaves. Therefore, the thicker leaves of A. hispidus var. insularis could be considered an adaptive feature to growth in coastal environments where droughts and salinity stress are common. Leaf thickening was correlated with cell size. As expected, the leaf cells of A. hispidus var. insularis were larger in size but fewer in number than those of $A$. hispidus var. hispidus. A decrease in leaf cell number may reflect a suppression of cell division under strong drought stress. Li et al. (2011) reported obvious reductions in mesophyll thickness in Campylotropis polyantha (Franch.) Schindl. cultivated under conditions of water deficiency. On the other hand, larger cell size in drought-tolerant genotypes was also reported in vascular tissues of Boehmeria nivea (L.) Gaud. (Liu et al., 2005). One of the causes of the difference in cell size between the coastal and inland varieties is that the large cell volume of $A$. hispidus var. insularis offers the plant the ability to store a greater amount of water in the leaf cells and compensate for the decrease in cell numbers. In fact, artificial tetraploid plants of Dendranthema nankingense (Nakai) Tzvel. with cells larger than those in normal diploid plants showed higher levels of abiotic stress tolerance, including drought and salinity stresses. Whether the tolerance was induced by increasing cell size was unclear though (Liu et al., 2011). Aster hispidus var. insularis may be able to grow along 
the coast by overcoming increased drought stress and soil salinity. For future studies, it will be necessary to investigate the correlation between cell size and water content in leaves of these species. In Japan, some other succulent taxa that evolved from related inland species and adapted to coastal environments are Cirsium maritimum Makino (Asteraceae), Dianthus japonicus Thunb. (Caryophyllaceae), and Arabis stelleri DC. var. japonica (A. Gray) Fr. Schm. (Cruciferae). Studies on these species are also necessary to confirm whether the anatomical differences found in this study represent a general tendency in the evolution of coastal plants from inland relatives.

Recent studies have provided some evidence for the coordination of cell proliferation and expansion of the leaf. For example, when cell proliferation in a leaf is reduced because of certain mutations, the reduction in the final leaf area is compensated for by an increase in the size of individual leaf cells. This phenomenon of compensation could aid in understanding the regulation of cell proliferation and expansion at the organ level (Tsukaya, 2003; 2008). In fact, Kim and Kende (2004) reported that a loss-of-function mutation in the AN3/GRF-INTERACTING FACTORl gene of Arabidopsis thaliana (L.) Heynh., which positively regulates cell proliferation in leaf primordia, resulted in a typical compensation syndrome (Horiguchi et al., 2005). In addition, several other genes that affect leaf cell proliferation have been described as causes of the compensation syndrome (Ali et al., 2007; Fujikura et al., 2007). The genetic background of cell proliferation and leaf expansion are very useful from the viewpoint of evolutionary developmental (evo-devo) studies of leaf differentiation between A. hispidus var. hispidus and var. insularis. Therefore, it would be very interesting to compare leaf morphologies of transgenic model plants by introducing these candidate homologues isolated from them.

\section{Acknowledgements}

We thank Drs. Ito K., Ichie T., Muramatsu Y. and Hirata A. for providing additional help. We also thank Dr. Tanaka N., Curator of the Makino Botanical Garden Herbarium, for permission to examine herbarium specimens. This study was partly supported by a Grant-in-Aid for Scientific Research from the Ministry of Education, Science and Culture of Japan (to J.Y. and T.F.).

\section{Reference}

Ali, F., Horiguchi, G., Yano, S., \& Tsukaya, H. (2007). Analysis of leaf development in fugu mutants of Arabidopsis reveals three compensation modes that modulate cell expansion in determinate organ. Plant Physiology, 144, 988-999.

Biebl, R., \& Kinzel, H. (1965). Blattbau und Salzhaushalt von Laguncularia racemosa (L.) Gaertn. f. und anderer Mangrovebäume auf Puerto Rico. Österreichischen Botanischen Zeitschrift, 112, 56-93. http://dx.doi.org/10.1007/BF01372978

Fujikura, U., Horiguchi, G., \& Tsukaya, H. (2007). Dissection of enhanced cell expansion processes in leaves triggered by a defect in cell proliferation, with reference to roles of endoreduplication. Plant Cell Physiology, 48, 278-286. http://dx.doi.org/10.1093/pcp/pcm002

Hayakawa, H., Tunala, Minamiya, Y., Ito, K., Gale, S. W., Yokoyama, J., Arakawa, R., \& Fukuda, T. (2012). Comparative study of leaf morphology in Aster hispidus Thunb. var. leptocladus (Makino) Okuyama (Asteraceae). American Journal of Plant Sciences, 3, 110-113. http://dx.doi.org/10.4236/ajps.2012.31011

Horiguchi, G., Kim, G. T., \& Tsukaya, H. (2005). The transcription factor AtGRF5 and the transcription coactivator AN3 regulate cell proliferation in leaf primordia of Arabidopsis thaliana. Plant Journal, 43, 68-78. http://dx.doi.org/10.1111/j.1365-313X.2005.02429.x

Ito, M., \& Soejima, A. (1995). Aster. In; Iwatsuki, K., Yamasaki K., Boufford, D.E., \& Ohba, H. (eds.), Flora of Japan (Vol. IIIb, Angiospermae, Dicotyledoneae, Sympetalae (b)). pp. 59-73. Kodansha, Tokyo.

Jackson, R. B., \& Jobbgy, E. G. (2005). From icy roads to salty streams. Proceedings of the National Academy of Sciences of the United States of America, 102, 14487-14488. http://dx.doi.org/10.1073/pnas.0507389102

Kaspari, M., Yanoviak, S. P., Dudley, R., Yuan, M., \& Clay, N. A. (2009). Sodium shortage as a constraint on the carbon cycle in an inland tropical rainforest. Proceedings of the National Academy of Sciences of the United States of America, 106, 19405-19409. http://dx.doi.org/10.1073/pnas.0906448106

Kim, J. H., \& Kende, H. (2004). A transcriptional coactivator, AtGIF1, is involved in regulating leaf growth and morphology in Arabidopsis. Proceedings of the National Academy of Sciences of the United States of America, 101, 13374-13379. http://dx.doi.org/10.1073/pnas.0405450101

Kitamura, S. (1982). COMPOSITAE (ASTERACEAE). In; Satake, Y., Ohwi, J., Kitamura, S., Watari, S., \& Tominari, T. (eds.), Wild flowers of Japan Herbaceous Plants (Vol. III, pp. 156-235). Heibonsha, Tokyo. 
Li, F-L., Bao, W-K., \& Wu, N. (2011). Morphological, anatomical and physiological responces of Camphyloropis polyantha (Franch.) Schindl. seedlings to progressive water stress. Scientia Horticurture, 127, 436-443. http://dx.doi.org/10.1016/j.scienta.2010.10.017

Liu, F., Liu, Q., Liang, X., Huang, H., \& Zhang, S. (2005). Morphological, anatomical, and physiological assesment of ramie [Boehmeria nivea (L.) Gaud.] tolerance to soil drought. Genetic Resources and Crop Evolution, 52, 497-506. http://dx.doi.org/10.1007/s10722-004-7071-3

Liu, S., Chen, S., Chen, Y., Guan, Z., Yin, D., \& Chen, F. (2011). In vitro induced tetraploid of Dendranthema nankingense (Nakai) Txvel. shows an improved level of abiotic stress tolerance. Scientia Horticurture, 127, 411-419. http://dx.doi.org/10.1016/j.scienta.2010.10.012

Matoh, T. (2001). Na. In; Mori, S., Mae, T., \& Yoneyama, T. (eds.), Plant nutrients (pp. 192-196). Buneido, Tokyo. (in Japanese)

Phillimore, A. B., \& Price, T. D. (2009). Ecological influences on the temporal pattern of speciation. In; Butlin, R., Bridle, J., \& Schluter, D. (eds.) Speciation and Patterns of diversity (pp. 240-256). Cambridge University Press. New York.

Shimizu, T. (1997). New Names Proposed in this Flora of Nagano Prefecture in 1997. In; Shimizu, T. (ed.), Flora of Nagano (pp. 1505-1511). Shinano Mainichi Shinbun. Nagano.

Suárez, N., \& Sobrado, M. A. (2000). Adjustments in leaf water relations of mangrove (Avicennia germinans) seedlings grown in a salinity gradient. Tree Physiology, 20, 277-282. http://dx.doi.org/10.1093/treephys/20.4.277

Tadano, T. (1993). Solt tolerance. In; Yamazaki, K., Sugiyama, T., Takahashi, E., Chino, M., Tadano, T., \& Asoh, S. (eds.) Plant nutrients and fertility. Asakura, Tokyo. (in Japanese)

Tsukaya, H. (2003). Organ shape and size: a lesson from studies of leaf morphogenesis. Current Opin Plant Biolology, 6, 57-62. http://dx.doi.org/10.1016/S1369526602000055

Tsukaya, H. (2008). Controlling size in multicellular organs: focus on the leaf. PLoS Biology, 6, e174. http://dx.doi.org/10.1371/journal.pbio.0060174

Yonekura, K., \& Kajita, T. (2003). BG Plants Japanese Name- Scienctific Name Index (YList). 